\title{
Influence of promoter region of TNF- $\alpha$ gene polymorphisms on anti-TNF treatment in rheumatoid arthritis: Preliminary report
}

\author{
Romatoid artritte TNF- $\alpha$ gen polimorfizmlerinin promoter bölgesinin anti-TNF \\ tedavisine etkisi:Ön çalışma \\ Türkan Turgay*, Ali Aydeniz ${ }^{* *}$,Sacide Pehlivan ${ }^{* *}$,Mustafa Pehlivan ${ }^{* * *}$, Özlem Altındağ ${ }^{* *}$, \\ Savaş Gürsoy** \\ *Sanko Üniversitesi,Health Science Faculty, Gaziantep, Türkiye \\ ${ }^{* *}$ Gaziantep Üniversitesi,Tıp Fakültesi,Fiziksel Tıp ve Rehabilitasyon AD, Gaziantep, Türkiye \\ ***Istanbul Üniversitesi, Istanbul Tıp Fakültesi, Tıbbi Biyoloji AD, Istanbul,Türkiye \\ ${ }^{* * * *}$ Gaziantep Üniversitesi, Tıp Fakültesi,Hematoloji AD, Gaziantep, Türkiye
}

\begin{abstract}
Purpose:The aim of this study was to explore the association between promotor polymorphisms in tumor necrosis factor $\alpha$ (TNF- $\alpha$ ) gene and disease activity,clinical parameters and response to different treatments in rheumatoid arthritis patients.

Materials and methods:We analyzed single nucleotide polymorphisms (-308,-238 and -857) in TNF- $\alpha$ gene in 65 patients with active RA who were treated with DMARD or anti-TNF therapy and in 70 control ones who had no rheumatologic problems. TNF- $\alpha$ genotyping were performed by the PCR-RFLP method.Clinical responses were compared by using disease activity score,VAS and health assessment questionnaire at baseline and after 6 months of treatment.

Results:A significant positive association was observed at TNF-857 CC genotype in RA patients $(p=0.046)$. At the six months the mean VAS,HAQ and DAS 28 improvement was not significant among groups. Improvement in DAS score was significantly better in -308 GG genotype than -308 AG genotype in anti-TNF subgroup. Conclusion:Our results suggest that TNF-857 CC genotype may be associated with susceptibility to disease and polymorphism in TNF-308 genotype may have an effect in response to therapy.Further studies should be warranted to establish TNF- $\alpha$ polymorphisms and susceptibility and response to treatment inrheumatoid arthritis patients.
\end{abstract}

Pam Med J 2017; 10 (3):216-220

Keywords:Rheumatoid arthritis,TNF- $\alpha$, gene,promoter polymorphisms.

\section{Özet}

Amaç:Bu çalışmanın amacı romatoid artrit hastalarında tümör nekrozis alfa geni (TNF- $\alpha$ ) promotor polimorfizmi ile hastalık aktivitesi,klinik parametreler ve değişik tedavilere yanıt arasında ilişkiyi belirlemektir.

Gereç ve yöntem:Çalışmamızda DMARD veya anti-TNF tedavisi alan 65 aktif romatoid artrit hastası ve 70 romatolojik hastalığı olmayan kontrol grubunda $-308,-238,-857$ içeren TNF-a'nın tek nukleotid polimorfizmi PCR-RFLP yöntemi kullanılarak analiz edildi.Tedaviye klinik yanıt hastalık aktivite skoru,görsel analog ölçek ve sağlık değerlendirme anketi kullanılarak başlangıçta ve 6 aylık tedavi sonrasında değerlendirildi.

Bulgular:Romatoid artrit hastalarında TNF-857 CC genotipinin anlamlı olarak fazla olduğu saptandı.Altı aylık tedavi sonunda grupların VAS;HAQ ve hastalık aktivite skorlarında iyileşme benzer bulundu.Buna rağmen hastalık aktivite skorlarında iyileşme TNF grubundaki hastalarda -308 GG genotipi olanlarda -308 AG genotipi olanlara göre daha iyiydi.

Sonuç:Romatoid artrit hastalarında TNF-857 CC genotipinin hastalığı yatkınlık sağlayabileceği;Aynı zamanda -308 genotinideki polimorfizmin tedaviye yanıtta bir rolü olabilir.Romatoid artrit hastalarında TNF- $\alpha$ polimorfizmi ve hastalığa yatkınlık ve tedaviye yanıtın belirlenmesinde ileri çalışmalara gereksinim vardır.

Pam Tıp Derg 2017; 10 (3):216-220

Anahtar sözcükler:Romatoid artrit,TNF-a,geni,promoter polimorfizmleri.

\footnotetext{
Sacide Pehlivan

Yazışma Adresi:Gaziantep Üniversitesi,Tıp Fakültesi,Fiziksel Tıp ve Rehabilitasyon AD,Gaziantep,Türkiye e-mail:sacide.pehlivan@istanbul.edu.tr
} 


\section{Introduction}

Rheumatoid arthritis [RA] is a chronic systemic inflammatory disease in which both genetic and environmental factors contribute to the etiology and/or clinical severity $[1,2]$. Because most estimates of the contribution of the HLA component to the overall genetic risk for $\mathrm{RA}$ are $<30 \%$, the identification of the other genetic factors helpful in predicting outcome and response to treatment. Tumor necrosis factor- $\alpha$ [TNF- $\alpha$ ] is a pro-inflammatory cytokine that have a pivotal role in regulating the inflammatory response in RA [3]. In patients with RA, TNF levels are chronically elevated in the blood and more specifically in the joints, but anti-TNF therapy has not been successful in all patients [4-6]. Since therapy with TNF- $\alpha$ blockers is expensive and bears substantial risks, it would be useful to be able to predict which patients will have improvement with therapy with TNF- $\alpha$ blockers [7].

The gene for TNF- $\alpha$ is highly polymorphic and there are many single nucleotide polymorphisms (SNPs) in TNF-a gene. It has been suggested in earlier studies that polymorphisms at -238 , -308 and -857 promoter regions may modulate the secretion of this cytokine and susceptibility a variety of immunological diseases besides RA $[8,9]$. But the investigation of three important gene loci in RA patients and response to therapy with TNF- $\alpha$ blockers are fewer.

The aim of the present study was to elucidate functional promoter polymorphisms of TNF- $\alpha$ in the RA patients and the association of these with disease severity and response to treatment with TNF- $\alpha$ blockers.

\section{Patients and Methods}

Sixty five RA patients were recruited from the Gaziantep University Medical School Hospital. The study was approved by the local ethical committee and informed consent was obtained from all patients. All subjects were Caucasians from the southern-east region of Turkey. RA was diagnosed according to the American College of Rheumatology criteria and subjects were evaluated at baseline and 6 months after. Thirty five patients received anti-TNF-alpha therapy (either etanercept $25 \mathrm{mg}$ subcutaneous twice weekly or Infliximab $3 \mathrm{mg} / \mathrm{kg}$ infusion at weeks $0,2,6$, and then every 8 weeks), 30 patients received disease-modifying antirheumatic drugs (DMARD) and 70 patients who have no rheumatologic disorders but admitted clinics for degenerative disorders were selected for control group.
Corticosteroids and non-steroidal anti inflammatory drugs were allowed as adjuvants at the treatment period for all groups. Disease activity was determined on the basis of defined parameters. The number of tender and swollen joints (28-joint count), duration of morning stiffness (in minutes), global health and disease activity on a 0-100 mm VAS and Disease Activity Score 28-joint Assessment (DAS28) was calculated. Functional assessment was carried out using the Health Assessment Questionnaire (HAQ) at baseline and after six months therapy.

Genomic DNA was extracted from mononuclear cells obtained from EDTA-treated peripheral venous blood using the salting out method [10]. TNF- $\alpha-308,-238$ and -857 polymorphisms were genotyped by PCR-RFLP and agarose gel electrophoresis [11]. The distribution of the genotypes of patients and control subjects were compared.

Analysis of data were performed using the computer software SPSS for Windows (version 13.0; SPSS Inc., Chicago, IL). The statistical significance of the differences between the patient and control groups was estimated by logistic regression analysis. Adjusted odds ratios (ORs) were calculated with a logistic regression model that controlled for gender and age and are reported at $95 \%$ confidence intervals $(\mathrm{CI})$. Differences in TNF allele frequencies between control group and patients were compared with Chi-square test and when needed Fisher's exact test. DAS Score is a numeric value which shows disease activity so, Mann-Whitney $U$ test was used for DAS score comparement between groups, A p-value less than 0.05 was considered statistically significant.

\section{Results}

The baseline characterististics of the groups and clinical evaluation at the baseline and after the 6 months of treatment are summarised in Table 1. Of the 65 RA patients, 47 were women and 18 were men. Mean age was 50 (38-65) in anti TNF- $\alpha$ group and 47 (29-78) in DMARD group. Mean disease duration was 9.5 \pm 10.4 years in anti-TNF- $\alpha$ group and $8.7 \pm 7.5$ in DMARD group.

The allelic distribution of the $-308,-238$ and -857 of the patients in the RA and healthy control group are shown in Table 2. Analysis of TNF-238 polymorphism showed increased frequency of $G G$ and decreased frequency of AG genotypes in the RA group. A significant positive association was observed at TNF-857 CC genotype in RA patients $(p=0.046)$. No 
differences in the genotype distribution of the TNF- $\alpha-238$ and -308 observed in patients when compared with the controls.

The mean VAS and HAQ score were not significant among both groups (Table 1). At the six months the mean DAS 28 improvement was not significant among groups $(p=0.051)$. Improvement in DAS 28 scores of RA patients after 6 months of treatment in correlation with $-308,-238$ and -857 of TNF-alpha gene promotor region are shown in Table 3. As shown, improvement in DAS28 response in -308GG genotype was significantly better than -308AG genotype in anti-TNF treated RA patients $(p=0.037)$. Whereas there were no significant differences in genotypic distribution of -238 and -857 polymorphims when DAS improvement in 6th month is considered $(p=0.457,0.662$ in order).

\section{Discussion}

TNF- $\alpha$ play significant role in RA and other inflammatory/autoimmune diseases [35]. Several studies suggested that promotor polymorphisms of TNF gene could predict the variations in TNF- $\alpha$ production and hence have an impact on severity of RA and response of the treatment [12-14].

Although there are some studies about SNPs within the TNF- $\alpha$ gene and an association was reported between systemic manifestations, response to treatment and radiologic progression etc. For this purpose we investigated the TNF- $\alpha$ $[-308,-238,-857]$ polymorphisms in Turkish RA patients and response to therapy. We found that RA patients with the -308 GG allel had better response to anti-TNF drugs than AG genotype. Recently, similar results were detected in 86

Table 1. Demographic and clinical data of the participants.

\begin{tabular}{|c|c|c|c|c|}
\hline & Anti TNF- $\alpha$ treatment & $\begin{array}{l}\text { DMARD } \\
\text { treatment }\end{array}$ & Control & $p^{\beta}$ \\
\hline No of patients & 35 & 30 & 70 & \\
\hline Age & $50(38-65)$ & $47(29-78)$ & $50(29-76)$ & N.S. \\
\hline Gender M/F & $8 / 27$ & $10 / 20$ & $23 / 47$ & N.S. \\
\hline DAS28 scores Week 0 & $4.93( \pm 1.59)$ & $5.28( \pm 1.05)$ & & N.S. \\
\hline Week 24 & $3.39( \pm 1.26)$ & $4.29( \pm 1.11)$ & & 0.004 \\
\hline Improvement in DAS28 & $1.54( \pm 0.97)$ & $0.98( \pm 1.00)$ & & 0.051 (N.S.) \\
\hline Week 0 & $0.92( \pm 0.76)$ & $0.67( \pm 0.55)$ & & N.S. \\
\hline Week 24 & $0.65( \pm 0.59)$ & $0.68( \pm 0.55)$ & & N.S. \\
\hline
\end{tabular}

Table 2. Comparison of TNF- $\alpha$ (-308), (-238) and (-857) gene polymorphism frequencies between patients with RA and healthy controls.

\begin{tabular}{|c|c|c|c|c|c|c|}
\hline Cytokine gene & Genotype & RA & $\begin{array}{l}\text { Healthy } \\
\text { Control }\end{array}$ & OR & $95 \% \mathrm{Cl}$ & $p$ \\
\hline & & $n^{a}(\%)$ & $n^{b}(\%)$ & & & \\
\hline \multirow[t]{3}{*}{ TNFa (-308) } & $\mathbf{A A}^{\#}$ & $-\quad(0)$ & $\begin{array}{ll}-\quad(0) \\
\end{array}$ & & & \\
\hline & $\mathrm{AG}^{\#}$ & $26(40)$ & 32 (48) & & & \\
\hline & $\mathbf{G G}^{\&}$ & $39(60)$ & $38 \quad(52)$ & $1.288^{*}$ & $0.642-2.585^{*}$ & $0.476^{*}$ \\
\hline \multirow[t]{3}{*}{ TNFa (-238) } & AA & $-\quad(0)$ & $\begin{array}{ll}- & (0)\end{array}$ & & & \\
\hline & AG & $2 \quad(3)$ & $7 \quad(10)$ & & & \\
\hline & GG & $63(97)$ & $63(90)$ & $3.309^{*}$ & $\begin{array}{l}0.650- \\
16.838^{*}\end{array}$ & $0.150^{*}$ \\
\hline \multirow[t]{3}{*}{ TNFa (-857) } & TT & $3 \quad(4.6)$ & $(12.8)$ & $0.328^{\&}$ & $0.085-1.270^{8}$ & $0.131^{\&}$ \\
\hline & TC & $12(18.4)$ & $24 \quad(34.3)$ & $0.648^{*}$ & $0.146-2.869^{*}$ & $0.567^{*}$ \\
\hline & $\mathrm{Cc}$ & $50(77)$ & $37 \quad(52.9)$ & $0.244^{*}$ & $0.061-0.975^{*}$ & $0.046^{*}$ \\
\hline
\end{tabular}


Table 3. Improvement in DAS28 scores in anti-TNFa (Etanercept/infliximab) and DMARD subgroups in correlation with the polymorphism at position $-308,-238$ and -857 of the TNFa gene.

\begin{tabular}{|c|c|c|c|c|c|c|c|}
\hline & & & $\begin{array}{l}\text { Anti TNFa } \\
\text { treatment }\end{array}$ & & & $\begin{array}{c}\text { DMAR } \\
\text { treatment }\end{array}$ & \\
\hline & & $\mathbf{n}$ & $\begin{array}{l}\text { Improvement in } \\
\text { DAS28 scores } \\
\text { Week 0/24 }\end{array}$ & $\mathbf{p}^{\beta}$ & $\mathbf{n}$ & $\begin{array}{l}\text { Improvement in } \\
\text { DAS28 scores } \\
\text { Week 0/24 }\end{array}$ & $\mathbf{p}^{\beta}$ \\
\hline \multirow[t]{2}{*}{ TNFa(-308) } & $A G^{\#}$ & 14 & $1.13( \pm 0.54)$ & & 12 & $0.88( \pm 0.84)$ & \\
\hline & $G^{*}$ & 21 & $1.82( \pm 1.11)$ & 0.037 & 18 & $1.05( \pm 1.12)$ & 0.723 \\
\hline \multirow[t]{2}{*}{ TNFa(-238) } & $A G$ & 1 & 2.37 & & 1 & 0.01 & \\
\hline & GG & 34 & $1.52( \pm 0.98)$ & 0.457 & 29 & $1.02( \pm 1.01)$ & 0.467 \\
\hline \multirow[t]{2}{*}{ TNFa(-857) } & $\mathrm{TT} / \mathrm{CT}$ & $2 / 9$ & $1.72( \pm 1.29)$ & & $3 / 1$ & $0.32( \pm 0.97)$ & \\
\hline & $\mathrm{CC}$ & 24 & $1.47( \pm 0.81)$ & 0.662 & 26 & $1.09( \pm 0.99)$ & 0.245 \\
\hline
\end{tabular}

Improvement; data are presented as mean \pm S.D.(sdt. Deviation),pß:Mann-Whitney U test, \#high expression,\& low expression,DAS28:Disease Activity Score in 28 joints

RA patients who were treated with etanercept [15]. However, Marotte et al. [16] reported controversial results that TNF- $\alpha-308$ SNP was not associated with response to infliximab therapy in RA patients. In another report, TNFa -308 GG promoter polymorphism had better response to adalimumab therapy than GA phenotype in 81 active RA patients [18].

We detected no significant difference about genotype distribution in TNF- $\alpha-308,-238$ SNPs in RA patients. However -857 CC SNP was significantly more frequent in RA group. Kang et al. [17] reported better response in -857 CT SNP in 70 Korean RA patients but in our series no difference was detected. Also baseline DAS 28 and VAS scores in CT/TT group was significantly lower than CC group in TNF-857 polymorphism. Ates et al. [19], also reported no differences in $-308,-238$ SNP but a significant association between having RA and $-1082 \mathrm{G}$ allele. In another study from Han population of the Eastern China, TNFa -308 differed significantly between RA patients and healthy controls [14]. Conversely in another study from Mexican RA patients -238 GG genotype showed increased frequency in RA patients when compared to healthy controls [20].

Genetic polymorphisms of TNF- $\alpha$ have been investigated in the pathogenesis and response to treatment of other inflammatory diseases. In large series, -308G/A and 238 GA polymorphisms of TNF- $\alpha$ were associated with asthma, systemic lupus erythematosus and juvenile RA in pediatric Mexican population [21]. Bonyadi [22] determined that allele and genotype distributions of $-1031 \mathrm{~T} / \mathrm{C}$ polymorphism was significantly different in Behçet's disease of Iranian Azeri Turks. Vargas-Alarcon reported that $-308 \mathrm{~A} / \mathrm{G}$ allel was increased in undifferentiated spondyloarthropathy group [23].

The main limitation of our study is subgroups of the anti-TNF drugs and also size of the groups that we stated as preliminary report.

Our results suggest that TNF-857 CC genotype may be associated with susceptibility to disease and that TNF- $\alpha$ gene polymorphisms might have an effect on RA patients and response to treatment.

Early diagnosis of RA and timely initiation of disaese modifying drugs prevent joint destruction, deformity and disability in RA.The identification of prognostic genetic biomarkers of treatment response is currently an important challange.

Conflict of interest:We do not have any conflict of interest.

\section{References}

1. Rego-Pérez I, Fernández-Moreno M, Blanco FJ. Gene polymorphisms and pharmacogenetics in rheumatoid arthritis. Curr Genomics 2008;9:381-393.

2. Coenen MJ, Gregersen PK. Rheumatoid arthritis:a view of the current genetic landscape. Genes Immun 2009;10:101-111.

3. Brennan FM, Maini RN, Feldmann M. TNF alpha--a pivotal role in rheumatoid arthritis? $\mathrm{Br} \mathrm{J}$ Rheumatol 1992;31:293-298.

4. Cuenca J, Cuchacovich M, Pérez C, et al. The -308 polymorphism in the tumour necrosis factor (TNF) gene promoter region and ex vivo lipopolysaccharideinduced TNF expression and cytotoxic activity in Chilean patients with rheumatoid arthritis. Rheumatology (Oxford) 2003;42:308-313.

5. Mugnier B, Balandraud N, Darque A, Roudier C, Roudier J, Reviron D. Polymorphism at position -308 of the tumor necrosis factor alpha gene influences outcome of infliximab therapy in rheumatoid arthritis. Arthritis Rheum 2003;48:1849-1852. 
6. Padyukov L, Lampa J, Heimbürger M, et al. Genetic markers for the efficacy of tumour necrosis factor blocking therapy in rheumatoid arthritis. Ann Rheum Dis 2003;62:526-529.

7. Bayley JP, Ottenhoff TH, Verweij CL. Is there a future for TNF promoter polymorphisms? Genes Immun 2004;5:315-329.

8. Constantin A, Dieudé $P$, Lauwers-Cancès $V$, et al. Tumor necrosis factor receptor II gene polymorphism and severity of rheumatoid arthritis. Arthritis Rheum 2004;50:742-747.

9. Martínez A, Fernández-Arquero M, Pascual-Salcedo $D$, et al. Primary association of tumor necrosis factorregion genetic markers with susceptibility to rheumatoid arthritis. Arthritis Rheum 2000;43:1366-1370.

10. Miller SA, Dykes DD, Polesky HF. A simple salting out procedure for extracting DNA from human nucleated cells. Nuc Acids Res 1988;16:1215.

11. Akcali A, Pehlivan S, Pehlivan M, Sever T, Akgul P,Neyal M. TNF-alpha promoter polymorphisms in multiple sclerosis: no association with -308 and -238 alleles, but the -857 alleles in associated with the disease in Turkish patients. Int J Immunogenet 2010;37:91-95.

12. Fonseca JE, Carvalho T, Cruz M, et al. Polymorphism at position -308 of the tumour necrosis factor alpha gene and rheumatoid arthritis pharmacogenetics. Ann Rheum Dis 2005;64:793-794.

13. Lo SF, Huang CM, Wu MC, Wu JY, Tsai FJ. Lack of association of tumor necrosis factor alpha gene polymorphism in patients with rheumatoid arthritis in central Taiwan. Rheumatol Int 2003;23:151-153.

14. Chen R, Fang M, Cai $Q$, et al. Tumor necrosis factor alpha -308 polymorphism is associated with rheumatoid arthritis in Han population of Eastern China. Rheumatol Int 2007;28:121-126.

15. Guis S, Balandraud N, Bouvenot J, et al. Influence of -308 A/G polymorphism in the tumor necrosis factor alpha gene on etanercept treatment in rheumatoid arthritis. Arthritis Rheum 2007;57:1426-1430.

16. Marotte H, Arnaud B, Diasparra J, Zrioual S, Miossec P. Association between the level of circulating bioactive tumor necrosis factor alpha and the tumor necrosis factor alpha gene polymorphism at -308 in patients with rheumatoid arthritis treated with a tumor necrosis factor alpha inhibitor. Arthritis Rheum 2008;58:1258-1263.

17. Kang CP, Lee KW, Yoo DH, Kang C, Bae SC. The influence of a polymorphism at position -857 of the tumour necrosis factor alpha gene on clinical response to etanercept therapy in rheumatoid arthritis. Rheumatology (Oxford) 2005;44:547-552.

18. Cuchacovich M, Soto L, Edwardes M, et al. Tumour necrosis factor [TNF] alpha -308 G/G promoter polymorphism and TNF alpha levels correlate with a better response to adalimumab in patients with rheumatoid arthritis. Scand J Rheumatol 2006;35:435440.

19. Ates O, Hatemi G, Hamuryudan V, Topal-Sarikaya A. Tumor necrosis factor-alpha and interleukin-10 gene promoter polymorphisms in Turkish rheumatoid arthritis patients. Clin Rheumatol 2008;27:1243-1248.

20. Rodríguez-Carreón AA, Zúñiga J, Hernández-Pacheco $\mathrm{G}$, et al. Tumor necrosis factor-alpha -308 promoter polymorphism contributes independently to HLA alleles in the severity of rheumatoid arthritis in Mexicans. J Autoimmun 2005;24:63-68.

21. Jiménez-Morales $\mathrm{S}$, Velázquez-Cruz R, Ramírez-Bello $\mathrm{J}$, et al. Tumor necrosis factor-alpha is a common genetic risk factor for asthma, juvenile rheumatoid arthritis, and systemic lupus erythematosus in a Mexican pediatric population. Hum Immunol 2009;70:251-256.

22. Bonyadi M, Jahanafrooz Z, Esmaeili M, et al. TNFalpha gene polymorphisms in Iranian Azeri Turkish patients with Behcet's Disease. Rheumatol Int 2009;30:285-289.

23. Vargas-Alarcón G, Casasola-Vargas J, RodríguezPérez JM, et al. Tumor necrosis factor-alpha promoter polymorphisms in Mexican patients with spondyloarthritis. Hum Immunol 2006;67:826-832. 